\title{
Best precision in measuring $Q p / Q s$ is achieved with quadratic, not linear, stationary tissue background correction in phase contrast velocity encoded CMR
}

\author{
Jannike Nickander ${ }^{1 *}$, Peder Sörensson ${ }^{1}$, Einar Heiberg ${ }^{2}$, Andreas Sigfridsson ${ }^{1}$, Martin Ugander $^{1}$ \\ From 19th Annual SCMR Scientific Sessions \\ Los Angeles, CA, USA. 27-30 January 2016
}

\section{Background}

Cardiovascular magnetic resonance (CMR) flow quantification for determining the ratio of flow between the pulmonary artery and aorta (Qp/Qs) is used to quantify cardiac shunts. Post-processing methods, including linear or quadratic stationary tissue background correction have been proposed to improve accuracy and precision in flow quantification. However, it is not known which method improves the flow quantification the most, and if patient characteristics effect the correction. We evaluated changes in accuracy and precision of $\mathrm{Qp} / \mathrm{Qs}$ following both linear and quadratic stationary tissue background correction, and investigated the effect on the precision of different patient characteristics. We hypothesized that the standard deviation of mean $\mathrm{Qp} / \mathrm{Qs}$ would be reduced following stationary background correction compared to uncorrected measures.

\section{Methods}

We enrolled consecutive patients ( $n=94$, age $50 \pm 16$ years, $62 \%$ male) referred for clinical CMR at $1.5 \mathrm{~T}$ (Siemens Aera) in whom the CMR report had no mention of cardiac shunts, malformations in the great vessels or persistent arrhythmias. A free-breathing non-segmented phase contrast velocity encoded sequence was used for throughplane velocity encoded imaging in the aorta and pulmonary artery. Flow quantification was performed both uncorrected and corrected for both linear and quadratic background phase correction using semi-automated methods with manual adjustments in freely available software

${ }^{1}$ Karolinska Institutet, Stockholm, Sweden

Full list of author information is available at the end of the article
(Segment version 2.0 R4534, Medviso AB, Lund, Sweden). Poor image quality was an exclusion criterion. Patient characteristics were dichotomized according to high and low values in relation to the median. Means were compared by the paired $t$-test $(t)$, and SDs by the $F$ test $(F)$.

\section{Results}

Patients with good image quality $(\mathrm{n}=91$, age $50 \pm 16$ years, $62 \%$ male) had mean $\mathrm{Qp} / \mathrm{Qs}$ uncorrected $1.04 \pm$ $0.110, \mathrm{Qp} / \mathrm{Qs}$ with linear correction $1.06 \pm 0.090(\mathrm{t} \mathrm{p}=$ $0.06, \mathrm{~F} \mathrm{p}=0.06)$, and quadratic correction $1.04 \pm 0.087(\mathrm{t}$ $\mathrm{p}=0.62, \mathrm{~F} \mathrm{p}=0.03$ ). Patient characteristics where quadratic background correction decreased variability were male sex $(\mathrm{p}=0.049)$, low height $(\mathrm{p}=0.03)$, low cardiac output $(p=0.04)$, a greater difference in stationary tissue area between anterior and posterior images halves for aortic and pulmonary images $(\mathrm{p}=0.04)$, and high angulation of pulmonary slice orientation in anterior-posterior $(\mathrm{p}=0.04)$ and right-left $(\mathrm{p}=0.04)$ directions.

\section{Conclusions}

Quadratic, not linear, stationary tissue background correction improved the precision of Qp/Qs compared to uncorrected measures in a clinical population. Patient characteristics where precision was improved with background correction included male sex, low height, low cardiac output, relatively greater amount of anterior stationary tissue, and more angulated orientation of pulmonary artery images.

\footnotetext{
Authors' details

${ }^{1}$ Karolinska Institutet, Stockholm, Sweden. ${ }^{2}$ Department of Clinical Physiology, Lund University, Lund, Sweden.
} 
Cite this article as: Nickander et al:: Best precision in measuring Qp/Qs

is achieved with quadratic, not linear, stationary tissue background

correction in phase contrast velocity encoded CMR. Journal of

Cardiovascular Magnetic Resonance 2016 18(Suppl 1):P245.

Submit your next manuscript to BioMed Central and take full advantage of:

- Convenient online submission

- Thorough peer review

- No space constraints or color figure charges

- Immediate publication on acceptance

- Inclusion in PubMed, CAS, Scopus and Google Scholar

- Research which is freely available for redistribution

Submit your manuscript at www.biomedcentral.com/submit 